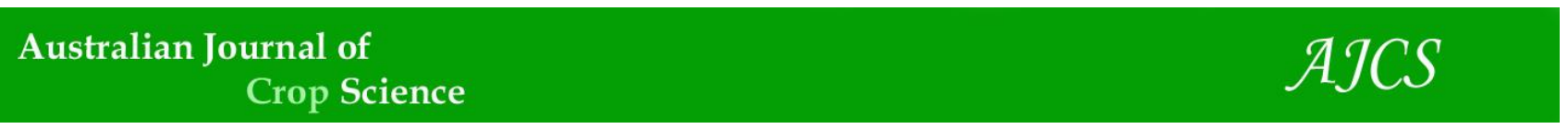

AJCS 12(01):87-92 (2018)

ISSN:1835-2707

doi: 10.21475/ajcs.18.12.01.pne749

\title{
Cherry tomato production on different organic substrates under protected environment conditions
}

\author{
Edilson Costa, Flávio Ferreira da Silva Binotti, Eliana Duarte Cardoso, David Barbosa Lima Júnior, Tiago \\ Zoz and Alan Mario Zuffo*
} Department of Crop Production, State University of Mato Grosso do Sul, 79540-000, Cassilândia, Mato Grosso do
Sul, Brazil

*Corresponding author: alan_zuffo@hotmail.com

\begin{abstract}
The cherry tomato (Lycopersicon esculentum var. cerasiforme) is gaining importance as an alternative crop, mainly for small farms that use family hand labor and organic management. In this study, we investigated the effects of organic substrate combinations of cattle manure (M), vermicompost (VC), and vermiculite (V) on the yield and quality of cherry tomato fruits. Cherry tomato plants of the cultivar Carolina were grown under greenhouse conditions in $5-\mathrm{L}$ pots. The five investigated substrate combinations were as follows: (T1) $80 \% \mathrm{M}+10 \% \mathrm{VC}+10 \% \mathrm{~V}$; (T2) $70 \% \mathrm{M}+15 \% \mathrm{VC}+15 \% \mathrm{~V}$; (T3) $60 \% \mathrm{M}+20 \% \mathrm{VC}+20 \% \mathrm{~V}$; (T4) $50 \% \mathrm{M}+25 \% \mathrm{VC}+25 \%$ $\mathrm{V}$; and (T5) $40 \% \mathrm{M}+30 \% \mathrm{VC}+30 \% \mathrm{~V}$. Plant growth, tomato yield, and physicochemical properties of the fruits were measured. The results showed that combinations of $50 \% \mathrm{M}+25 \% \mathrm{VC}+25 \% \mathrm{~V}$ and $40 \% \mathrm{M}+30 \% \mathrm{VC}+30 \% \mathrm{~V}$ led to the best growth and adaptation of cherry tomato plants, resulting in larger and more rounded fruits. The substrate containing $40 \% \mathrm{M}+30 \% \mathrm{VC}+30 \% \mathrm{~V}$ resulted in higher numbers of fruits per plant. Different substrate combinations did not affect the chemical quality of the fruit. Therefore, our study has provided valuable information on the use of organic substrates in cherry tomato production under protected environment conditions. Based on our results, the different combinations of cattle manure, vermicompost, and vermiculite used in this study represent excellent options for reducing production costs and re-using organic byproducts.
\end{abstract}

Keywords: Cattle manure; Lycopersicon esculentum; vermicompost; vermiculite

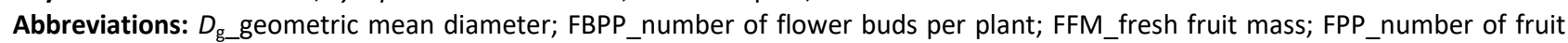
per plant; $L$ _length; LPP_number of leaves per plant; $M_{-}$cattle manure; $R \_$roundness; RCI_relative chlorophyll index; $S \_s u r f a c e$ area; $T_{-}$thickness; TSS_total soluble solids; TTA_total titratable acidity; V_vermiculite; VC_vermicompost; $W \_$width; $\Phi_{-}$sphericity.

\section{Introduction}

Cherry tomatoes [Lycopersicon esculentum Mill. var. cerasiforme (Dunal) Alef.] are small, round, cherry-sized fruits of the Solanaceae family. They are popular in Brazil partly due to their versatility and ease of combining with a wide variety of uses in salads, appetizers, snacks, sauces, and soups (Filgueira, 2013). This species is characterized by its relatively high contents of lycopene, vitamin-A, vitamin-B, folic acid, fructose, and minerals such as phosphorus, potassium, calcium, and magnesium (Filgueira, 2013). Cherry tomatoes are also an excellent source of antioxidant compounds such as polyphenols and carotenoids (Kalogeropoulos et al., 2012), which help to prevent cancer and cardiovascular and circulatory diseases caused by oxidative stress (Gong et al., 2006). Substrate composition, environmental conditions and fertilizer management, among other factors, can influence the yield and fruit quality of the cherry tomato. According to Ferreira et al. (2003), the nutritional requirements of tomato plants can be met with chemical or organic fertilizers. Cherry tomatoes can be produced in the field or greenhouse. For production in a greenhouse environment, pots containing substrates can be used. Such substrates can be formulated from organic, mineral or artificial sources, or combinations of these.
Suitable organic sources of animal origin are cattle, poultry, and goat manure as well as vermicompost. Vermiculite and sand are the most used sources of mineral origin, while phenolic foam and styrofoam are commonly used artificial sources (Pio et al., 2005; Bastos et al., 2007). Costa et al. (2015) found that the highest fruit yields of the cherry tomato cultivars Pêra Amarela, Pêra Vermelha, and Carolina were obtained with substrate combinations containing $50 \%$ cassava foliage $+50 \%$ of cattle manure and $25 \%$ cassava foliage $+25 \%$ commercial substrate $+25 \%$ poultry manure + $25 \%$ cattle manure. The use of animal manure from agricultural fields, composted and chemically analyzed, is a viable alternative as a material for substrate composition because of its low cost; also, it is organic, recyclable, and has considerable amounts of nutrients for plant growth. Pribetic et al. (2000) reported the highest yield and fruit quality of tomatoes is achieved with the use of organic compounds complemented with mineral fertilizers.

Vermicompost has high levels of phosphorus, calcium, and potassium and can be used in substrate formulation, including seedling production in organic systems (Araújo Neto et al., 2009). Andriolo et al. (1999) found that the addition of vermicompost resulted in better growth and 
yield of tomatoes compared with the use of carbonized rice husk. According to Samawat et al. (2001), the use of vermicompost combined with chemical fertilizers can improve the growth of tomato plants. Vermiculite, as a mineral substrate, has a high water retention capacity, high porosity, low density, high cation exchange capacity (CEC), and properties to maintain an adequate physical quality of substrates.

The objectives of the present study were to investigate the effects of different combinations of cattle manure, vermicompost, and vermiculite on yield and quality of cherry tomato fruits and to assess the potential use of organic substrates in a tomato production system.

\section{Results and Discussion}

\section{Effects of substrate on growth and development}

From the beginning of plant growth until 47 days after sowing, plants grown in substrates with fewer cattle manure (M) and greater amounts of vermicompost (VC) and vermiculite $(V)$ were taller (Table 1 ). Substrates with large amounts of $\mathrm{V}$ provided taller plants, while substrates with higher amounts of VC provided greater nutrient availability, allowing better plant adaptation and growth due to aeration and adequate water supply. Also, the nutrients present in VC allowed adequate plant nutrition. We observed greater uniformity and stability in growth from 54 to 75 days after sowing, when plants were of similar heights (Table 1 ).

Araújo-Neto et al. (2009) described difficulties in finding a substrate with all the desirable characteristics; therefore, it is necessary to mix different materials to obtain an adequate substrate. Vermicompost is an organic fertilizer and can improve chemical, physical, and biological soil properties; it can also be used in seedling production. Araújo-Neto et al. (2009) stated that VC has high levels of phosphorus, calcium, and potassium and can be part of the substrate composition in organic seedling production. Diniz et al. (2006) recommended a combination of VC with $40 \% \mathrm{~V}$. Vermiculite improves aeration and substrate water retention, favoring seedling growth and development.

According to the literature and based on the findings of our study, the combination of vermiculite with vermicompost in higher proportions promotes growth and development of cherry tomato plants. At 140 days after sowing, Albuquerque Neto and Peil (2012) evaluated tomato genotypes in a fall/winter hydroponic system and found that the cherry tomato cv. 'Yubi' (Feltrin'), with determinate growth, reached a height of $0.57 \mathrm{~m}$, while the other cultivars with indeterminate growth reached heights of around $2.0 \mathrm{~m}$, except for the cultivar 'Gaucho', which reached only $1.72 \mathrm{~m}$. In this study, the cultivar 'Carolina' (Feltrin ), with indeterminate growth, reached a height of $1.57 \mathrm{~m} 75$ days after sowing (Table 1 ).

Similar results were obtained regarding the number of leaves from 33 to 54 days after sowing, where the highest addition of VC resulted in plants with a greater number of leaves (Table 1). To some degree, high leaf numbers enable larger solar energy capture and a greater net photosynthetic rate, resulting in increased photosynthate production because of the upper leaf surface area, as reported by Pivetta et al. (2007).
At 45 days after seedling transplanting, Maia et al. (2013) evaluated the number of leaves of the cherry tomato cv. 'Pori' in different combinations of cattle manure and the commercial substrate and found a mean value of 25 leaves per plant. These results are lower than the value observed in this study, which was 47 leaves 47 days after sowing. The high number of leaves observed in the present study may be due to the combinations of $\mathrm{M}+\mathrm{VC}+\mathrm{V}$, indicating that the use of this mixture resulted in plants with a greater number of leaves and a better photosynthetic conversion.

There was little variation in the stem diameter between the different substrate combinations tested, although we found higher values for substrates with greater amounts of VC and V (Table 1). Regarding the number of flower buds, a larger value (14.7 units) was observed for the substrate containing $40 \% \mathrm{M}+30 \% \mathrm{VC}+30 \% \mathrm{~V}$ (Table 1). High stature plants with higher numbers of leaves and probably greater numbers of lateral shoots obtained a larger number of flower buds in substrates with higher amounts of vermicompost.

The relative chlorophyll index $(\mathrm{RCl})$ ranged from 6.89 to 13.49 (Table 2). For tomato plants, Guimarães et al. (1999) observed higher $\mathrm{RCl}$ values, ranging from 43.8 to 45.5 . In a laboratory test, the same authors obtained chlorophyll values from 77.3 to $83.6 \mathrm{mg} \mathrm{cm}^{-2}$. In our study, at $33,47,61$, and 68 days after sowing, there were no differences among the treatments regarding $\mathrm{RCl}$ (Table 2). At 40 days after sowing, the substrate containing $50 \% \mathrm{M}+25 \% \mathrm{VC}+25 \% \mathrm{~V}$ resulted in the highest $\mathrm{RCl}$ values, and at 54 days after sowing, the substrate containing $40 \% \mathrm{M}+30 \% \mathrm{VC}+30 \% \mathrm{~V}$ reached higher values.

\section{Effects of substrate on biometric characteristics of fruits}

Information on dimensional fruit properties, such as geometric mean diameter $\left(D_{\mathrm{g}}\right)$, roundness $(R)$, and sphericity $(\Phi)$, can support the development of preprocessing machine dimensions and even the processing and classification of the tomatoes per se. In general, cherry tomato fruits growing in a substrate containing $40 \% \mathrm{M}+30 \% \mathrm{VC}+30 \% \mathrm{~V}$ were more circular and spherical compared to the fruits on other substrates (Table 3). However, it should be noted that in all treatments, the fruits were more oblong than round. The substrates containing $50 \% \mathrm{M}+25 \% \mathrm{VC}+25 \% \mathrm{~V}$ and $40 \% \mathrm{M}+$ $30 \% \mathrm{VC}+30 \% \mathrm{~V}$ resulted in fruits with larger surface areas (Table 3).

The average yield obtained in this study was $507 \mathrm{~g}$ per plant (Table 3). For the cultivar 'Dellycia', Malheiros et al. (2012) achieved a lower yield than that in the present study, i.e., $287.52 \mathrm{~g}$ per plant, with 100.87 fruits per plant and a fresh fruit mass of $2.85 \mathrm{~g}$ per fruit. The fresh fruit mass obtained by these authors was three times lower than that in the present study (Table 3). Gusmão et al. (2006) evaluated different tomato hybrids grown in different substrates and obtained the lowest yield with the hybrid Cheri $\left(5.06 \mathrm{~kg} \mathrm{~m}^{-2}=1265 \mathrm{~g}\right.$ per plant; with 360.61 fruits per plant and $3.51 \mathrm{~g}$ per fruit). This yield is significantly higher than the mean yield achieved with the cultivar 'Carolina' in the present study ( $555.27 \mathrm{~g}$ per plant; with 63.93 fruits per plant and $8.67 \mathrm{~g}$ per fruit). It should be noted that the fresh fruit mass obtained in this work was 2.5 times greater than that achieved by Gusmão et al. (2006) (Table 3). 
Table 1. Effects of different combinations of cattle manure (M), vermicompost (VC) and vermiculite (V) on plant height, stem diameter, number of leaves and number of flower buds per plant during growth and development of cherry tomato plants (Lycopersicon esculentum var. cerasiforme, cv. 'Carolina'). Cassilândia, MS, Brazil, 2013.

\begin{tabular}{|c|c|c|c|c|c|c|c|c|}
\hline \multirow[b]{2}{*}{ Substrate combinations } & \multicolumn{8}{|c|}{ Days after sowing } \\
\hline & 26 & 33 & 40 & 47 & 54 & 61 & 68 & 75 \\
\hline & \multicolumn{8}{|c|}{ Plant height $(\mathrm{cm})$} \\
\hline $80 \% \mathrm{M}+10 \% \mathrm{VC}+10 \% \mathrm{~V}$ & $23.3 \mathrm{bc}$ & $40.1 \mathrm{c}$ & $68.7 c$ & $95.8 \mathrm{~cd}$ & $106.5 \mathrm{a}$ & $128.0 \mathrm{a}$ & $144.3 \mathrm{~b}$ & $155.0 \mathrm{a}$ \\
\hline $70 \% \mathrm{M}+15 \% \mathrm{VC}+15 \% \mathrm{~V}$ & $23.1 \mathrm{c}$ & $42.8 \mathrm{bc}$ & $73.1 \mathrm{ab}$ & $94.9 \mathrm{~d}$ & $108.3 \mathrm{a}$ & $126.0 \mathrm{a}$ & $145.3 a b$ & 153.7 a \\
\hline $60 \% M+20 \% V C+20 \% V$ & $24.5 \mathrm{abc}$ & $43.5 \mathrm{bc}$ & $72.0 \mathrm{bc}$ & $97.0 \mathrm{bc}$ & $108.3 \mathrm{a}$ & $129.3 \mathrm{a}$ & $146.3 \mathrm{ab}$ & 154.7 a \\
\hline $50 \% M+25 \% \mathrm{VC}+25 \% \mathrm{~V}$ & $25.7 \mathrm{a}$ & $47.2 \mathrm{a}$ & $76.0 \mathrm{a}$ & $97.3 \mathrm{~b}$ & $106.4 \mathrm{a}$ & $127.3 \mathrm{a}$ & $146.1 \mathrm{ab}$ & $154.0 \mathrm{a}$ \\
\hline \multirow[t]{2}{*}{$40 \% M+30 \% \mathrm{VC}+30 \% \mathrm{~V}$} & $25.6 \mathrm{ab}$ & $46.2 \mathrm{ab}$ & $72.7 \mathrm{ab}$ & 99.6 a & $109.2 \mathrm{a}$ & $129.9 \mathrm{a}$ & $148.7 \mathrm{a}$ & $157.0 \mathrm{a}$ \\
\hline & \multicolumn{8}{|c|}{ Stem diameter (mm) } \\
\hline $80 \% \mathrm{M}+10 \% \mathrm{VC}+10 \% \mathrm{~V}$ & $7.1 \mathrm{a}$ & $8.1 \mathrm{c}$ & $9.9 \mathrm{~b}$ & $10.7 \mathrm{a}$ & $10.6 a b$ & $10.4 \mathrm{a}$ & $11.6 \mathrm{a}$ & $12.2 \mathrm{a}$ \\
\hline $70 \% \mathrm{M}+15 \% \mathrm{VC}+15 \% \mathrm{~V}$ & $7,0 \mathrm{a}$ & $8.4 b$ & $10.5 a b$ & $10.1 \mathrm{ab}$ & $10.9 a b$ & $10.6 \mathrm{a}$ & $11.4 \mathrm{a}$ & $12.5 \mathrm{a}$ \\
\hline $60 \% M+20 \% V C+20 \% V$ & $7.2 \mathrm{a}$ & $8.6 \mathrm{~b}$ & $10.0 \mathrm{~b}$ & $9.8 \mathrm{~b}$ & $10.4 \mathrm{~b}$ & $10.1 \mathrm{a}$ & $11.5 \mathrm{a}$ & $12.4 \mathrm{a}$ \\
\hline $50 \% M+25 \% \mathrm{VC}+25 \% \mathrm{~V}$ & $7.3 \mathrm{a}$ & $9.2 \mathrm{a}$ & $10.0 \mathrm{~b}$ & $10.5 \mathrm{ab}$ & $10.6 a b$ & $10.1 \mathrm{a}$ & $11.4 \mathrm{a}$ & $12.3 \mathrm{a}$ \\
\hline \multirow[t]{2}{*}{$40 \% \mathrm{M}+30 \% \mathrm{VC}+30 \% \mathrm{~V}$} & $7.4 \mathrm{a}$ & $8.7 \mathrm{~b}$ & $10.7 \mathrm{a}$ & $10.3 \mathrm{ab}$ & $11.4 \mathrm{a}$ & $10.2 \mathrm{a}$ & $11.4 \mathrm{a}$ & $12.7 \mathrm{a}$ \\
\hline & \multicolumn{8}{|c|}{ Number of leaves per plant (unit) } \\
\hline $80 \% \mathrm{M}+10 \% \mathrm{VC}+10 \% \mathrm{~V}$ & $7.9 \mathrm{a}$ & $12.5 \mathrm{~b}$ & $26.8 \mathrm{~b}$ & $46.6 \mathrm{bc}$ & $60.7 d$ & $69.3 \mathrm{a}$ & $71.1 \mathrm{a}$ & $73.9 \mathrm{ab}$ \\
\hline $70 \% \mathrm{M}+15 \% \mathrm{VC}+15 \% \mathrm{~V}$ & $7.9 \mathrm{a}$ & $13.0 \mathrm{ab}$ & $25.9 \mathrm{~b}$ & $46.6 \mathrm{bc}$ & $63.5 \mathrm{ab}$ & $69.3 \mathrm{a}$ & $71.3 \mathrm{a}$ & $73.2 \mathrm{~b}$ \\
\hline $60 \% M+20 \% V C+20 \% V$ & $8.4 \mathrm{a}$ & $13.5 \mathrm{ab}$ & $26.5 \mathrm{~b}$ & $46.2 \mathrm{c}$ & $63.3 \mathrm{bc}$ & $69.0 \mathrm{a}$ & $71.7 \mathrm{a}$ & $73.3 \mathrm{~b}$ \\
\hline $50 \% M+25 \% \mathrm{VC}+25 \% \mathrm{~V}$ & $8.4 \mathrm{a}$ & $13.8 \mathrm{a}$ & $28.2 \mathrm{a}$ & $47.4 \mathrm{~b}$ & $62.4 \mathrm{c}$ & $69.2 \mathrm{a}$ & $71.7 \mathrm{a}$ & $73.4 \mathrm{~b}$ \\
\hline \multirow[t]{2}{*}{$40 \% \mathrm{M}+30 \% \mathrm{VC}+30 \% \mathrm{~V}$} & $8.5 \mathrm{a}$ & $13.5 \mathrm{a}$ & $26.3 \mathrm{~b}$ & $49.3 \mathrm{a}$ & $64.5 \mathrm{a}$ & $69.1 \mathrm{a}$ & $72.3 \mathrm{a}$ & $75.0 \mathrm{a}$ \\
\hline & \multicolumn{8}{|c|}{ Number of flower buds per plant (unit) } \\
\hline $80 \% \mathrm{M}+10 \% \mathrm{VC}+10 \% \mathrm{~V}$ & $1.00 \mathrm{a}$ & $2.27 \mathrm{~b}$ & $6.93 \mathrm{ab}$ & $12.60 \mathrm{a}$ & $12.33 \mathrm{c}$ & $11.53 \mathrm{a}$ & $10.67 \mathrm{~b}$ & $12.00 \mathrm{ab}$ \\
\hline $70 \% \mathrm{M}+15 \% \mathrm{VC}+15 \% \mathrm{~V}$ & $1.07 \mathrm{a}$ & $2.07 \mathrm{~b}$ & $7.13 \mathrm{ab}$ & $11.00 \mathrm{~b}$ & $13.80 \mathrm{~b}$ & $11.53 \mathrm{a}$ & $10.67 \mathrm{~b}$ & $11.60 \mathrm{bc}$ \\
\hline $60 \% M+20 \% V C+20 \% V$ & $1.13 \mathrm{a}$ & $2.07 \mathrm{~b}$ & $6.87 \mathrm{ab}$ & $11.40 \mathrm{~b}$ & $12.93 \mathrm{c}$ & $11.13 \mathrm{a}$ & $8.60 \mathrm{c}$ & $11.67 \mathrm{bc}$ \\
\hline $50 \% M+25 \% \mathrm{VC}+25 \% \mathrm{~V}$ & $1.27 \mathrm{a}$ & $2.27 \mathrm{~b}$ & $7.27 \mathrm{a}$ & $12.53 \mathrm{a}$ & $14.07 \mathrm{ab}$ & $11.60 \mathrm{a}$ & $12.73 \mathrm{a}$ & $11.20 \mathrm{c}$ \\
\hline $40 \% M+30 \% V C+30 \% V$ & $1.33 \mathrm{a}$ & $2.93 \mathrm{a}$ & $6.80 \mathrm{~b}$ & $12.67 \mathrm{a}$ & $14.67 \mathrm{a}$ & $12.13 \mathrm{a}$ & $8.67 c$ & $12.40 \mathrm{a}$ \\
\hline
\end{tabular}

Values represented by different letters in each column indicate significant differences (Tukey test, $\mathrm{p}<0.05$ )

Table 2. Effects of different combinations of cattle manure (M), vermicompost (VC) and vermiculite (V) on the relative chlorophyll index during growth and development of cherry tomato plants (Lycopersicon esculentum var. cerasiforme, cv. 'Carolina'). Cassilândia, MS, Brazil, 2013.

\begin{tabular}{|c|c|c|c|c|c|c|c|c|}
\hline \multirow[b]{2}{*}{ Substrate combinations } & \multicolumn{8}{|c|}{ Days after sowing } \\
\hline & 26 & 33 & 40 & 47 & 54 & 61 & 68 & 75 \\
\hline & \multicolumn{8}{|c|}{ Relative chlorophyll index } \\
\hline $80 \% \mathrm{M}+10 \% \mathrm{VC}+10 \% \mathrm{~V}$ & $7.91 \mathrm{~b}$ & 9.86 a & $9.19 \mathrm{~b}$ & $10.26 \mathrm{a}$ & $11.18 \mathrm{bc}$ & $6.89 a$ & $11.01 \mathrm{a}$ & $13.35 \mathrm{a}$ \\
\hline $70 \% \mathrm{M}+15 \% \mathrm{VC}+15 \% \mathrm{~V}$ & $8.88 \mathrm{a}$ & $9.05 \mathrm{a}$ & $9.37 \mathrm{~b}$ & $9.63 \mathrm{a}$ & $10.63 \mathrm{c}$ & $7.67 \mathrm{a}$ & $10.57 \mathrm{a}$ & $11.90 \mathrm{ab}$ \\
\hline $60 \% M+20 \% V C+20 \% V$ & $8.61 \mathrm{ab}$ & $9.05 \mathrm{a}$ & $9.09 \mathrm{~b}$ & $9.70 \mathrm{a}$ & $13.09 a b$ & $7.45 \mathrm{a}$ & $9.41 \mathrm{a}$ & $11.20 a b$ \\
\hline $50 \% M+25 \% \mathrm{VC}+25 \% \mathrm{~V}$ & $8.87 a$ & 9.93 a & $10.29 \mathrm{a}$ & $9.93 \mathrm{a}$ & $10.62 \mathrm{c}$ & $7.90 \mathrm{a}$ & $9.51 \mathrm{a}$ & $11.38 \mathrm{ab}$ \\
\hline $40 \% \mathrm{M}+30 \% \mathrm{VC}+30 \% \mathrm{~V}$ & $8.73 \mathrm{a}$ & $10.07 \mathrm{a}$ & $9.04 b$ & $10.03 \mathrm{a}$ & $13.49 \mathrm{a}$ & $7.90 \mathrm{a}$ & $10.83 \mathrm{a}$ & $10.74 \mathrm{~b}$ \\
\hline
\end{tabular}

Values represented by different letters in each column indicate significant differences (Tukey test, $\mathrm{p}<0.05)$.

Table 3. Effects of different combinations of cattle manure (M), vermicompost (VC) and vermiculite (V) on fruit length (L), width $(W)$, thickness $(T)$, geometric mean diameter $\left(D_{\mathrm{g}}\right)$, surface area $(S)$, sphericity $(\Phi)$, roundness $(R)$, number of fruit per plant (FPP), fresh fruit mass (FFM) and fruit yield per plant of cherry tomato (Lycopersicon esculentum var. cerasiforme, cv. 'Carolina'). Cassilândia, MS, Brazil, 2013.

\begin{tabular}{|c|c|c|c|c|c|}
\hline Substrate combinations & $L(\mathrm{~mm})$ & $W(\mathrm{~mm})$ & $T(\mathrm{~mm})$ & $D_{\mathrm{g}}(\mathrm{mm})$ & $S\left(\mathrm{~mm}^{2}\right)$ \\
\hline $80 \% \mathrm{M}+10 \% \mathrm{VC}+10 \% \mathrm{~V}$ & $27.82 \mathrm{c}$ & $21.04 \mathrm{~b}$ & $18.62 \mathrm{bc}$ & $22.18 b$ & $1544.86 \mathrm{~b}$ \\
\hline $70 \% \mathrm{M}+15 \% \mathrm{VC}+15 \% \mathrm{~V}$ & $28.58 \mathrm{a}$ & $20.84 b$ & $18.52 \mathrm{c}$ & $22.26 \mathrm{~b}$ & $1556.42 \mathrm{~b}$ \\
\hline $60 \% \mathrm{M}+20 \% \mathrm{VC}+20 \% \mathrm{~V}$ & 28.12 bc & $21.13 b$ & $18.42 \mathrm{c}$ & $22.20 \mathrm{~b}$ & $1548.01 \mathrm{~b}$ \\
\hline $50 \% \mathrm{M}+25 \% \mathrm{VC}+25 \% \mathrm{~V}$ & $28.52 \mathrm{a}$ & $21.60 \mathrm{a}$ & $18.97 \mathrm{~b}$ & $22.70 \mathrm{a}$ & 1618.29 a \\
\hline $40 \% \mathrm{M}+30 \% \mathrm{VC}+30 \% \mathrm{~V}$ & $28.36 \mathrm{ab}$ & $22.02 \mathrm{a}$ & $19.38 \mathrm{a}$ & $22.96 \mathrm{a}$ & 1655.75 a \\
\hline Substrate combinations & $\Phi(\%)$ & $R(\%)$ & FPP (unit) & FFM (g/fruit) & Yield (g/plant) \\
\hline $80 \% \mathrm{M}+10 \% \mathrm{VC}+10 \% \mathrm{~V}$ & $79.71 \mathrm{~b}$ & $75.64 \mathrm{~b}$ & $55.67 \mathrm{~b}$ & $8.45 \mathrm{a}$ & $471.81 \mathrm{a}$ \\
\hline $70 \% \mathrm{M}+15 \% \mathrm{VC}+15 \% \mathrm{~V}$ & $77.88 \mathrm{c}$ & $72.90 \mathrm{c}$ & $55.80 \mathrm{~b}$ & $9.63 \mathrm{a}$ & $541.40 \mathrm{a}$ \\
\hline $60 \% M+20 \% V C+20 \% V$ & $78.94 \mathrm{~b}$ & $75.12 b$ & $55.33 \mathrm{~b}$ & $8.62 \mathrm{a}$ & $477.76 \mathrm{a}$ \\
\hline $50 \% \mathrm{M}+25 \% \mathrm{VC}+25 \% \mathrm{~V}$ & $79.58 \mathrm{~b}$ & $75.76 \mathrm{~b}$ & $55.60 \mathrm{~b}$ & $8.81 \mathrm{a}$ & $489.56 \mathrm{a}$ \\
\hline $40 \% \mathrm{M}+30 \% \mathrm{VC}+30 \% \mathrm{~V}$ & 80.95 a & 77.64 a & $63.93 \mathrm{a}$ & $8.67 \mathrm{a}$ & $555.27 \mathrm{a}$ \\
\hline
\end{tabular}

Values represented by different letters in each column indicate significant differences (Tukey test, $\mathrm{p}<0.05$ ). 
Table 4. Effects of different combinations of cattle manure (M), vermicompost (VC) and vermiculite (V) on total soluble solids (TSS), total titratable acidity (TTA) and pH of cherry tomato fruits (Lycopersicon esculentum var. cerasiforme, cv. 'Carolina'). Cassilândia, MS, Brazil, 2013.

\begin{tabular}{llll}
\hline Substrate combinations & TSS $\left(^{\circ}\right.$ Brix) & TTA (\%) & pH \\
\hline $80 \% E+10 \% H+10 \% V$ & $9.20 \mathrm{a}$ & $0.44 \mathrm{a}$ & $3.71 \mathrm{a}$ \\
$70 \% \mathrm{E}+15 \% \mathrm{H}+15 \% \mathrm{~V}$ & $9.23 \mathrm{a}$ & $0.46 \mathrm{a}$ & $3.70 \mathrm{a}$ \\
$60 \% \mathrm{E}+20 \% \mathrm{H}+20 \% \mathrm{~V}$ & $9.13 \mathrm{a}$ & $0.42 \mathrm{a}$ & $3.71 \mathrm{a}$ \\
$50 \% \mathrm{E}+25 \% \mathrm{H}+25 \% \mathrm{~V}$ & $9.25 \mathrm{a}$ & $0.42 \mathrm{a}$ & $3.73 \mathrm{a}$ \\
$40 \% \mathrm{E}+30 \% \mathrm{H}+30 \% \mathrm{~V}$ & $9.43 \mathrm{a}$ & $0.44 \mathrm{a}$ & $3.70 \mathrm{a}$ \\
\hline
\end{tabular}

Values represented by the different letters in each column indicate significant differences (Tukey test, $p<0.05)$.

Table 5. Physical and chemical characteristics of cattle manure and vermicompost used in the study.

\begin{tabular}{|c|c|c|}
\hline Characteristic & Cattle manure & Vermicompost \\
\hline $\mathrm{pH}$ in water & 5.40 & 6.90 \\
\hline Dry matter (\%) & 61.10 & 86.50 \\
\hline Organic carbon $\left(\mathrm{g} \mathrm{kg}^{-1}\right)$ & 141.00 & 163.00 \\
\hline Total nitrogen $\left(\mathrm{g} \mathrm{kg}^{-1}\right)$ & 18.40 & 14.80 \\
\hline $\mathrm{C} / \mathrm{N}$ ratio $^{+}$ & 7.65 & 11.00 \\
\hline Total phosphorus $\left(\mathrm{g} \mathrm{kg}^{-1}\right)$ & 1.71 & 4.46 \\
\hline Potassium $\left(\mathrm{g} \mathrm{kg}^{-1}\right)$ & 1.00 & 1.00 \\
\hline Calcium $\left(\mathrm{g} \mathrm{kg}^{-1}\right)$ & 15.05 & 26.70 \\
\hline Magnesium $\left(\mathrm{g} \mathrm{kg}^{-1}\right)$ & 0.70 & 12.50 \\
\hline Sulfur $\left(\mathrm{g} \mathrm{kg}^{-1}\right)$ & 1.95 & 3.53 \\
\hline Copper $\left(\mathrm{mg} \mathrm{kg}^{-1}\right)$ & 18.50 & 30.00 \\
\hline Zinc $\left(\mathrm{mg} \mathrm{kg}^{-1}\right)$ & 125.00 & 130.00 \\
\hline Iron (mg kg-1) & $6,830.00$ & $14,800.00$ \\
\hline Manganese $\left(\mathrm{mg} \mathrm{kg}^{-1}\right)$ & 214.00 & 370.00 \\
\hline Boron (mg kg ${ }^{-1}$ ) & 14.00 & 14.40 \\
\hline
\end{tabular}

These results suggest that the cultivar or hybrid influences tomato yield and fruit size. Assessing the spacing and conduction system of the cherry tomato cultivars 'Perinha Água Branca' and 'Super Sweet' in organic farming, Azevedo et al. (2010) found results similar to those in the present study, i.e., a mean mass of $7.36 \mathrm{~g}$ per fruit, a length $(L)$ of $28.57 \mathrm{~mm}$, and a width $(W)$ of $25.55 \mathrm{~mm}$. However, the number of fruits per plant (95) and yield per plant (693.33 g per plant) were higher than those obtained in this study (Table 3).

Different substrate combinations did not affect tomato fruit yield (Table 3). This result is in contrast with results found by Costa et al. (2015) that higher fruit yields of the tomato cultivars 'Yellow Pear', 'Red Pear', and 'Carolina' were obtained with substrates containing $50 \%$ cassava foliage $+50 \%$ cattle manure and $25 \%$ cassava foliage $+25 \%$ commercial substrate $+25 \%$ poultry manure $+25 \%$ cattle manure.

In a comparative morphological analysis of cherry tomato fruits from three cropping systems, Stertz et al. (2005) reported that the fruits of the conventional system showed a mass and length of $13.23 \mathrm{~g}$ and $24.84 \mathrm{~mm}$, respectively; the organic system resulted in a mass and length of $17.33 \mathrm{~g}$ and $31.77 \mathrm{~mm}$, respectively, and the fruits of the hydroponic system resulted in a mass and length of $114.50 \mathrm{~g}$ and 30.06 $\mathrm{mm}$, respectively. These fruit mass values were higher than those obtained for the cultivar 'Carolina' in our study; however, the fruit length values were similar (Table 3).

\section{Effect of substrate on fruit chemical composition}

In the present study, the total soluble solids (TSS) value was $9.3^{\circ}$ Brix, while the total titratable acidity (TTA) was 0.44 , and the $\mathrm{pH}$ value was 3.71 (Table 4). Similar results were reported by Crisanto-Juárez et al. (2010), who found values of TSS ranging from 4.5 to $9.3^{\circ}$ Brix, TTA values from 0.45 to 1.07 , and $\mathrm{pH}$ values from 3.63 to 4.30 .

\section{Materials and Methods}

\section{Study site}

The experiment was carried out from May to October 2013 in Mato Grosso do Sul State University (UEMS), in the municipality of Cassilândia, MS, Brazil (19006'48" S, 5144'03" W), at $516 \mathrm{~m}$ above sea level. The climate, according to the Köppen classification, is Aw: humid tropical with dry winters and warm summers. The region has a welldefined dry season between May and September, with a mean annual temperature of $24.1^{\circ} \mathrm{C}$ and mean annual rainfall of $1520 \mathrm{~mm}$.

Plants were grown under greenhouse conditions, with all sides covered by black nets ( $50 \%$ shading), comprising an area of $144 \mathrm{~m}^{2}$ ( $8 \mathrm{~m}$ wide $\times 18 \mathrm{~m}$ long $\times 3.5 \mathrm{~m}$ high).

\section{Experimental design}

The treatments consisted of five substrate combinations, arranged in a completely randomized design with five replications. The investigated substrate combinations were as follows: (T1) $80 \%$ cattle manure $+10 \%$ vermicompost + $10 \%$ vermiculite; (T2) $70 \%$ cattle manure $+15 \%$ vermicompost $+15 \%$ vermiculite; (T3) $60 \%$ cattle manure + $20 \%$ vermicompost $+20 \%$ vermiculite; (T4) $50 \%$ cattle manure $+25 \%$ vermicompost $+25 \%$ vermiculite; and (T5) $40 \%$ cattle manure $+30 \%$ vermicompost $+30 \%$ vermiculite. Before use, the fresh cattle manure was subjected to aerobic composting for 30 days. The composted material was then dried, homogenized, and sifted through a 5-mm mesh. The vermicompost was obtained from a cattle slaughterhouse 
located in the municipality of Dois Irmãos do Buriti, MS, Brazil. The byproducts or organic residues from the slaughterhouse supplied to the worms for vermicomposting mainly consisted of rumen, viscera, blood, and fats. The main physicochemical characteristics of cattle manure and vermicompost are shown in Table 5.

Four cherry tomato seeds (Lycopersicon esculentum var. cerasiforme, cv. 'Carolina') were sown in 5-L plastic pots on May 10, 2013, containing the different substrate combinations. Twenty days after sowing, seedlings were thinned to one plant per pot. Tomato plants were spaced at $0.5 \times 0.5 \mathrm{~m}$ and attached vertically to bamboo stakes.

In all treatments, $35 \mathrm{~g}$ of $\mathrm{N}$ and $16 \mathrm{~g}$ of $\mathrm{K}$ per pot were applied 60 days after sowing (DAS). The $\mathrm{N}$ rate as urea $(45 \%$ $\mathrm{N})$ and the $\mathrm{K}$ rate as potassium chloride $\left(60 \% \mathrm{~K}_{2} \mathrm{O}\right)$ were divided into 12 and six topdressing applications. The fertilizers were applied as a $20-\mathrm{mL}$ solution, previously diluted in pure water, to the side of each plant. Substrate water content was monitored daily and maintained near field capacity. Control of the tomato leafminer [Tuta absoluta (Meyrick) (Lepidoptera: Gelechiidae)], Silverleaf whitefly [Bemisia tabaci (Gennadius) (Hemiptera: Aleyrodidae)], green peach aphid [Myzus persicae (Sulzer) (Hemiptera: Aphididae)], and potato aphid [Macrosiphum euphorbiae (Thomas) (Hemiptera: Aphididae)] was carried out using 10 organic insecticide applications $(1.5 \mathrm{~mL}$ of neem oil per liter of water).

\section{Traits measured}

\section{Growth and reproductive measurements}

From 26 days after sowing, plant height, stem diameter, number of leaves per plant (LPP), and number of flower buds per plant (FBPP) were measured once a week. Plant height $(\mathrm{cm})$ was measured from the base of the plant to the top of the apical meristem using a tape measure. Stem diameter $(\mathrm{mm})$ was measured at the base of the plant stem using a digital caliper. The numbers of leaves or flower buds were obtained by counting the leaves or flowers on the stem, respectively. The relative chlorophyll index $(\mathrm{RCl})$ was measured once a week using a portable Minolta Chlorophyll Meter SPAD-502 (Soil and Plant Analysis Development). Measurements were performed in triplicate on the upper third of each expanded leaf, and average values were used for analysis.

The tomato harvest began on July 29,2013 , (80 DAS) and was completed on October 17, 2013 (160 DAS). The number of fruit per plant (FPP) and fresh fruit mass (FFM) were measured. Fruit number was determined as the total number of fruit per plant. Fresh fruit mass was the average fruit mass per plant in grams, calculated by dividing the total fruit mass by the total fruit number harvested on each plant; the weights were measured using a digital balance with an accuracy of $0.001 \mathrm{~g}$. The yield was the total fruit mass in grams of each plant.

For each cherry tomato fruit, three linear dimensions were measured by using a digital caliper with $0.01 \mathrm{~mm}$ accuracy, including length $(L)$, width $(W)$, and thickness $(T)$. The $L, W$, and $T$ were the lengths of the major, intermediate, and minor diameter of cherry tomato fruits, respectively. The fruit geometric mean diameter $\left(D_{\mathrm{g}}\right)$, surface area $(S)$, sphericity $(\Phi)$, and roundness $(R)$ were calculated as suggested by Mohsenin (1986):

$D_{\mathrm{g}}=(L W T)^{1 / 3}$

$S=\pi\left(D_{\mathrm{g}}\right)^{2}$

$\Phi=\left(\frac{D g}{L}\right) \times 100$

$R=\left(\frac{W}{L}\right) \times 100$

Where, $D_{\mathrm{g}}$ is the geometric mean diameter $(\mathrm{mm}), S$ is the fruit surface area $\left(\mathrm{mm}^{2}\right), \Phi$ is sphericity (\%), and $R$ is the roundness (\%) of cherry tomato fruits. At the end of the experiment (160 DAS), 15 tomato fruits were randomly collected from each treatment to measure total soluble solids (TSS), total titratable acidity (TTA), and fruit $\mathrm{pH}$. The TSS ( ${ }^{\circ}$ Brix) was determined in a juice sample using a hand refractometer with a range of 0 to $32^{\circ}$ Brix, and solutions of $0.2^{\circ}$ Brix were used to determine TSS by placing one to two drops of clear juice on the prism. The refractometer was calibrated against distilled water ( $0 \%$ reading TSS) before each reading. For determining the TTA (\%) an aliquot of 10 $\mathrm{mL}$ of juice was diluted with $500 \mathrm{~mL}$ of water. After dilution, $30 \mathrm{~mL}$ of the solution was measured into a beaker, $0.5 \mathrm{~mL}$ (about four drops) of phenolphthalein indicator was added, and the solution was titrated to a permanent pink color with $50 \mathrm{mmol} \mathrm{L}^{-1} \mathrm{NaOH}$. The $\mathrm{pH}$ values of the tomato juice were measured with a pH meter (Model TEC-2, Tecnal Company).

\section{Statistical analysis}

Data were subjected to analysis of variance (F-test, $p=0.05$ ), and the means were compared by Tukey's test at the 0.05 level of confidence. All analyses were performed using Sisvar 5.3 software for Windows (Statistical Analysis Software, UFLA, Lavras, MG, BRA).

\section{Conclusion}

The combination of $50 \%$ manure $+25 \%$ vermicompost $+25 \%$ vermiculite and $40 \%$ manure compost $+30 \%$ vermicompost $+30 \%$ vermiculite provided the best conditions and adaptation for cherry tomato plant growth, yield, and chemical quality. Therefore, different combinations of cattle manure, vermicompost, and vermiculite have the potential for use as organic substrates in cherry tomato production under protected environment conditions.

\section{Acknowledgements}

This research was funded by CNPq (National Council for Scientific and Technological Development) and FUNDECT (Foundation to Support the Development of Education, Science, and Technology of the Mato Grosso do Sul State).

\section{References}

Albuquerque Neto AAR, Peil RMN (2012) Produtividade biológica de genótipos de tomateiro em sistema hidropônico no outono/inverno. Hortic Bras. 30(4):613-61. 
Andriolo JL, Duarte TS, Ludke L, Skrebsky EC (1999) Caracterização e avaliação de substratos para o cultivo do tomateiro fora do solo. Hortic Bras. 17(3):215-219.

Araújo Neto SE, Araújo de Azevedo JM, Oliveira Galvão RD, Barbosa de Lima Oliveira E, Ferreira RL (2009) Produção de muda orgânica de pimentão com diferentes substratos. Ciênc Rural. 39(5):1408-1413.

de Azevedo VF, Abboud ACS, do Carmo MGF (2010) Row spacing and pruning regimes on organically grown cherry tomato. Hortic Bras. 28(4):389-394.

Bastos DC, Pio R, Scarpare Filho JA, Libardi MN, de Almeida LFP, Entelmann FA (2007) Diferentes substratos na produção de porta-enxertos de caramboleira. Ciênc Agrotec. 31(2):312-316.

Costa E, do Espírito Santo TL, da Silva AP, da Silva LE, de Oliveira LC, Benett CGS, Benett KSS (2015) Ambientes e substratos na formação de mudas e produção de frutos de cultivares de tomate cereja. Hortic Bras. 33(1):110-118.

Crisanto-Juárez AU, Vera-Guzmán AM, Chávez-Servia JL, Carrillo-Rodríguez JC (2010) Calidad de frutos de tomates silvestres (Lycopersicon esculentum var. cerasiforme Dunal) de Oaxaca, México. Rev Fitotec Mex. 33(4):7-13.

Diniz KA, Guimarães STMR, Luz JMQ (2006) Húmus como substrato para a produção de mudas de tomate, pimentão e alface. Biosci J. 22(3):63-70.

Ferreira MMM, Ferreira GB, Fontes PCR, Dantas JP (2003) Produção do tomateiro em função de doses de nitrogênio e da adubação orgânica em duas épocas de cultivo. Hortic Bras. 21(3):468-473.

Filgueira FAR (2013) Novo manual de olericultura : agrotecnologia moderna na produção e comercialização de hortaliças. Third revision. Federal University of Viçosa, Viçosa.

Gong Y, Sohn H, Xue L, Firestone GL, Bjeldanes LF (2006) 3,3'-Diindolylmethane is a novel mitochondrial $\mathrm{H}(+)$-ATP synthase inhibitor that can induce p21(Cip1/Waf1) expression by induction of oxidative stress in human breast cancer cells. Cancer Res. 66(9):4880-4887.

Guimarães TG, Fontes PCR, Pereira PRG, Alvarez VH, Monnerat PH (1999) Teores de clorofila determinados por medidor portátil e sua relação com formas de nitrogênio em folhas de tomateiro cultivados em dois tipos de solo. Bragantia. 58(1):209-216.

Gusmão MTA, Gusmão SAL, Araújo JAC (2006) Produtividade de tomate tipo cereja cultivado em ambiente protegido e em diferentes substratos. Hortic Bras. 24(4):431-436.

Kalogeropoulos N, Chiou A, Pyriochou V, Peristeraki A, Karathanos VT (2012) Bioactive phytochemicals in industrial tomatoes and their processing byproducts. LWT - Food Sci Technol. 49(2):213-216.

Maia JTLS, Clemente JM, de Souza NH, de Oliveira Silva J, Martinez HEP (2013) Adubação orgânica em tomateiros do grupo cereja. Biotemas. 26(1):37-44.

Malheiros SM, Silva EFF, de Medeiros PRF, Pedrosa EMR, Rolim MM, Santos AN (2012) Cultivo hidropônico de tomate cereja utilizando-se efluente tratado de uma indústria de sorvete. Rev Bras Eng Agric Ambient. 16(10):1085-1092.

Mohsenin NN (1986) Physical properties of plant and animal materials. Second revised. Gordon and Breach Science Publishers, New York.

Pio R, Araújo JPC, Bastos DC, Alves ASR, Entelmann FA, Scarpare Filho JA, Mourão Filho FAA (2005) Substratos no enraizamento de estacas herbáceas de figueira oriundas da desbrota. Ciênc Agrotec. 29(3):604-609.

Pivetta CR, Tazzo IF, Maass GF, Streck NA, Heldwein AB (2007) Emissão e expansão foliar em três genótipos de tomateiro (Lycopersicon esculentum Mill.). Ciênc Rural. 37(5):1274-1280.

Pribetic D, Jurisic M, Vlaketic I (2000) Tomato yield depending on fertilization. Agron Glas. 62:345-356.

Samawat S, Lakzian A, Zamirpour A (2001) The effect of vermicompost on growth characteristics of tomato. Agric Sci Tech. 15:83-89.

Stertz SC, Espírito Santo AP, Bona C, Freitas RJS (2005) Análise morfológica comparativa de frutos tomate cereja provenientes de três sistemas de cultivo. Sci Agric. 62(3):296-298. 